\title{
REPRODUCTIVE SYSTEM AND POLLEN FLOW IN PROGENIES OF Qualea grandiflora Mart., A TYPICAL SPECIES OF THE BRAZILIAN CERRADO ${ }^{1}$
}

\author{
Lia Maris Orth Ritter Antiqueira² e Paulo Yoshio Kageyama ${ }^{3}$
}

\begin{abstract}
This study analyzed the reproductive system and the pollen dispersion pattern of Qualea grandiflora progenies. This is a typical species from the Brazilian Cerrado about which there are not too many studies from the genetics point of view. The study was conducted in an area of 2.2 hectares located in the Conservation Unit managed by the Forest Institute of the state of São Paulo, Brazil (Assis State Forest). Total genomic DNA of 300 seeds from 25 plants (12 seeds from each plant) was extracted and amplified using specific primers to obtain microsatellite markers. Results showed that selfing is frequent among adults and progenies, and the species reproduces by outcrossing between related and unrelated individuals $(0.913)$. The single-locus outcrossing rate was 0.632 , which indicates that mating between unrelated individuals is more frequent than between related plants. The selfing rate was low (0.087), that is, the species is allogamous and self-fertilization is reduced. About $35 \%$ of the plants in the progenies were full-sibs, and about $57 \%$, half-sibs. Besides, about $8 \%$ of the progenies were selfing siblings. The genetic differentiation coefficient within progenies was 0.139 , whereas the fixation rate was about $27 \%$. The estimate of the effective size revealed that the genetic representativeness of descent was lower than expected in random mating progenies: The analyzed samples corresponded to only 13.2 individuals of an ideal panmictic population. In environmental recovery programs, seeds, preferably from different fruits, should be collected from 95 trees to preserve the genetic diversity of the species.
\end{abstract}

Keywords: Conservation genetics; Genetic diversity; SSR.

\section{SISTEMA REPRODUTIVO E FLUXO DE PÓLEN EM PROGÊNIES DE Qualea grandiflora Mart., ESPÉCIE TÍPICA DO CERRADO}

\begin{abstract}
RESUMO - Este trabalho analisou o sistema reprodutivo e o padrão de dispersão de pólen em progênies de Qualea grandiflora Mart. É uma espécie típica do Cerrado brasileiro ainda pouco analisada do ponto de vista genético. A área de estudo possui 2,2 hectares e localiza-se em Unidade de Conservação administrada pelo Instituto Florestal do Estado de São Paulo (Floresta Estadual de Assis). Foram extraídas amostras de DNA genômico total de 300 sementes provenientes de 25 matrizes (12 sementes de cada matriz), as quais foram amplificadas utilizando iniciadores específicos para obtenção de marcadores microssatélites. Os resultados indicaram que adultos e progênies possuem taxa de endogamia elevada e a espécie se reproduz por cruzamentos entre indivíduos parentes e não aparentados $(0,913)$. A taxa uniloco foi de 0,632, indicando que há mais cruzamentos entre não parentes do que entre parentes. A taxa de autofecundação foi baixa $(0,087)$, ou seja, a espécie é alógama, com pouca pré-disposição para autofecundação. Aproximadamente, 35\% das plantas dentro de progênies eram parentes no grau de irmãos-completos e cerca de 57\%, de meios-irmãos. Além disso, aproximadamente 8\% das progênies eram irmãos de autofecundação. O coeficiente de coancestria estimado nas progênies foi 0,139 , enquanto o índice de fixação, de aproximadamente $27 \%$. A estimativa do tamanho efetivo indicou que a representatividade genética da descendência é inferior à esperada em progênies de cruzamentos aleatórios: as amostras analisadas correspondem a apenas 13,2 indivíduos de uma população panmítica ideal. A coleta de sementes para uso em programas de recuperação ambiental precisa ser realizada em 95 árvores e, de preferência, de frutos distintos, para manter a diversidade genética da espécie.
\end{abstract}

Palavras-chave: Genética da Conservação; Diversidade genética; Microssatélites.

\footnotetext{
${ }^{1}$ Recebido em 06.05.2013 aceito para publicação em 09.12.2014

${ }^{2}$ Universidade Tecnológica Federal do Paraná, Departamento Acadêmico de Ensino, Ponta Grossa, PR - Brazil. E-mail: $<$ liaantiqueira@utfpr.edu.br>.

${ }^{3}$ Universidade de São Paulo, Escola Superior de Agricultura Luiz de Queiroz, Departamento de Ciências Florestais, Piracicaba, SP - Brazil. E-mail: <pkageyama@usp.br>.
} 


\section{INTRODUCTION}

The expansion of the agricultural frontiers in Brazil resulted in the fragmentation of native vegetation. The Cerrado areas in the country have been limited to small fragments surrounded by monoculture. In consequence, the genetic variability of the species is reduced due to a bottleneck effect, genetic derivation and restriction to gene flow, and there is an increase in selfing, isolation and gene divergence between populations.

The increase of selfing may lead to changes in the reproductive patterns of species and to the fixation of deleterious alleles, which may raise the chances of population extinction (COLLEVATTI et al., 2001b; VENCOVSKY, 1987; ZUCCHI et al., 2003).

The preservation of genetic variation among native species is a great challenge for biological conservation programs (BARRET; KOHN, 1991). Genomics has become an important tool, as it allows biodiversity to be studied by means of the molecular diversity existent in natural populations of several species, either under direct or indirect anthropogenic impact (SOLÉ-CAVA, 2001). Strongly criticized by conservationists in the late 1980 s for being restricted to the estimates of heterozygosity in populations subjected to population bottlenecks, the initiatives related to the conservation genomics are currently being leveraged to the level of paramount importance in international conservation programs (TORRES, 2003).

Investments to promote studies about the Cerrado gained importance only in the last decade, when this region was included in the list of world biodiversity hotspots (MITTERMEIER et al., 2005). Since then, important results have been achieved in studies aimed at the conservation of typical species, such as Dipteryx alata Vogel (SOARES et al., 2008; TARAZI et al., 2010), Copaifera langsdorffii Desf. (TARAZI, 2009), Hymenaeae stygonocarpa Mart. ex. Hayne (MORENO et al., 2009) and Tabebuia ochracea (Cham.) Standl. (MOREIRA et al., 2009).

There has been growing concern about the evaluation of the genetic consequences that habitat fragmentation may have on species, and scientists have investigated the genetic fragility of populations and the strategies to preserve threatened species. Knowledge about their reproductive system helps to understand the dynamics of pollen and seed dispersion (GOMES;
MOURA, 2010), evaluate possible cases of hybridization or introgression, identify vulnerable populations, estimate genetic risks of extinction, and determine minimal conservation areas and number of seeds to be collected in recovery programs(BREDE; BEEBEE, 2004; CROZIER et al., 1997; FRANKHAM, 2003, 2005; HITCHINGS; BEEBEE, 1997).

Qualea grandiflora Mart (Vochysiaceae) is a typical tree of the Brazilian Cerrado, popularly known as "pau terra" in Brazil. It may grow to a height of 20 meters and has a thick bark with transverse and longitudinal fissures covering its trunk (ALMEIDA et al., 1998). It is a common species in several Cerrado physiognomies, where there are high densities of individuals per hectare, usually in an aggregate distribution (ANTIQUEIRA; KAGEYAMA, 2013). Is pollinated by moths (Sphingidae) and seed dispersal is anemocoric (ALMEIDA et al., 1998).

Its wood is used to produce charcoal, logs, wood ceilings and boxes. In traditional medicine, it is used to treat asthma and ulcers. Dyes are extracted from its fruit and seeds. The species is recommended for the recovery of degraded areas, as well as for its landscaping potential (PAULA; ALVES, 1997; ALMEIDA et al., 1998; AYRES et al., 2008).

This study investigated the reproductive system and pollen flow pattern of Qualea grandiflora Mart progenies using microsatellite markers, since their reproduction system is not known in detail and it is not known how representative gene contained in seeds derived open pollination in terms of effective size being held in banks.

The assumptions for this study are: (i) the species is not self-incompatible and (ii) as the seed dispersion by wind occurs predominantly in the vicinity of parent trees, it is expected that trees located spatially close to each other have some degree kinship.

\section{MATERIALAND METHODS}

The study area is in the state of São Paulo, Brazil, in a Conservation Unit (Assis State Forest - 22॰36'00"'S and $50^{\circ} 24^{\prime} 28^{\prime \prime} \mathrm{W}$ ), managed by the Forest Institute. The physiognomy is Cerrado sensu strict (RIBEIRO; WALTER, 1998), with Braquiaria sp. and mean tree coverage of 46.3\% (PINHEIRO; DURIGAN, 2009).

In an area of two hectares, 25 plants were geographically located and identified using the criterion

Revista Árvore, Viçosa-MG, v.39, n.2, p.337-344, 2015

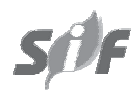


of the greatest number of fruit available in the trees and the greatest distance one from the other. Six fruit were collected from each tree, and two seeds were extracted from each fruit, at a total of 12 seeds per plant (300 samples).

The DNA from the seeds was extracted using a cetyltrimethylammonium bromide (CTAB) method (DOYLE; DOYLE, 1990), 3\% at concentration (FERREIRA; GRATTAPAGLIA, 1998). Using liquid nitrogen, macerated one seed was in each tube (Eppendorffs) of $2.0 \mathrm{ml}$, using 900 ì of buffer for each sample.

PCR amplifications were performed in 13 ì L reaction volume consisting of buffer (10 mM Tris- $\mathrm{HCl}$ [pH 8.4], $50 \mathrm{mM} \mathrm{KCl}$, and $0.5 \mathrm{mM} \mathrm{MgCl2}$ ) and containing 7.5 ng of genomic DNA, 2,5 ìg/ml of BSA, $0.2 \mathrm{mM}$ of each primer, $0.25 \mathrm{mM}$ dNTPs, and $1 \mathrm{U}$ Taq DNA polymerase (Invitrogen).

Eight primer pairs (Table 1) developed by Ritter et al. (2012) for Q. grandiflora Mart were selected for amplification. The amplification program for all primers consisted of an initial denaturing step at $96^{\circ} \mathrm{C}$ for 2 min, followed by 29 cycles of amplification $\left(94^{\circ} \mathrm{C}[1\right.$ $\mathrm{min}], 1 \mathrm{~min}$ at the specific annealing temperature of each primer pair, $72{ }^{\circ} \mathrm{C}$ [1 min $]$ ) and a final elongation step at $72{ }^{\circ} \mathrm{C}$ for $7 \mathrm{~min}$.

Amplification products were confirmed by electrophoresis in 5\% denaturing polyacrylamide gels and silver stained (CRESTE et al., 2001). Allele scoring was carried out using the $10 \mathrm{bp}$ DNA Ladder (Invitrogen) as size standard.

The population reproduction system was analyzed according to the mixed mating model described by Ritland and Jain (1981), which assumes that: i) alleles from different loci segregate independently; ii) the pollen pool is homogeneous for outcrossing with any genotype in the population; and iii) there is no selection between fertilization and the evaluation of genetic markers.

Results were obtained using the Multilocus MLTR software (RITLAND, 2009), which calculates the multilocus and the single-locus outcrossing rates for the population; the allele frequencies of the ovule and the pollen were calculated according to the method of maximal likelihood using the expectation maximization (EM) algorithm. The EM algorithm (DEMPSTER et al., 1977; MCCLACHLAN; KRISHNAN, 1997) is a powerful tool to maximize the likelihood estimate with incomplete data (missing data, unknown elements, latent variables, censored data etc.).

To estimate the standard error of the parameters, the software used the bootstrap method (EFRON, 1979), with 10.000 resamplings and $95 \%$ confidence interval, in which the sampling unit for the estimates of individual and population outcrossing rates were the plants in the progenies and the progenies, respectively. Biparental inbreeding rate and the multilocus and single-locus correlation of paternity, from which the proportion of full-sibs and half-sibs in outcrossing progenies, were also estimated.

The indices of fixation for adults and progenies and the mean genetic differentiation coefficient within progenies were obtained by means of analysis of gene frequencies of the population using the GDA software (LEWIS; ZAYKIN, 2000), 95\% confidence interval based on the standard error, and the jackknife method for calculation across loci. The effective population size

Table 1 - Forward and Reverse sequences used in studies of Q. grandiflora Mart., annealing temperatures in degrees Celsius and registration number in GeneBank.

Tabela 1 - Sequências Forward e Reverse utilizadas nos estudos de Q. grandiflora Mart com as respectivas temperaturas de anelamento em graus Celsius e número de registro no GeneBank.

\begin{tabular}{|c|c|c|c|c|}
\hline PRIMER & FORWARD & REVERSE & $\mathrm{T}\left({ }^{\circ} \mathrm{C}\right)$ & GENEBANK \\
\hline Qgr1 & CACTGGCGATTCATTTCTCA & AGCCCAACCGAGTAAACAAG & 58 & JN230425 \\
\hline Qgr3 & GCGACGATGAGTTTCATTAGC & ATGATTGAGAATGGGGGACT & 58 & JN230426 \\
\hline Qgr4 & GATACAATGTCGGGGAGGAC & CCACGTAAAACTCAATTCATCG & 56 & JN230427 \\
\hline Qgr7 & ATCAGAGCACTCAAGCAACG & CAGCAAACTAATGGAGGAGGA & 58 & JN230428 \\
\hline Qgr11 & CGCAAAATCCCCATCTTATC & TGCTCCTTGAGTGCTGTGA & 58 & JN230429 \\
\hline Qgr12 & GGGCTTTATGTCTTTTGGTTTG & СтTстTстTстTсCTCGCAGA & 58 & JN230430 \\
\hline Qgr13 & TGAATGTGTTCCAAACCAGTG & AAGTGTGCGTGTGCGTGT & 54 & JN230431 \\
\hline Qgr20 & CATGCGTAAGCGTAAAATCTC & TACATTGCCACGGGAGTAAG & 58 & JN230432 \\
\hline
\end{tabular}

Fonte: Ritter et al., 2012

Source: Ritter et al., 2012. 
of adults and progenies was calculated using the Hill method (1981), as modified by Waples (2006).

\section{RESULTS}

Allele frequencies in ovule and pollen in the 8 loci under study were equal, which indicated that there was no violation of the mixed mating model described by Ritland and Jain (1981). Therefore, it was possible to estimate the multilocus outcrossing rate accurately.

The estimate of the fixation rate was greater among adult individuals $(0.38)$ than progenies $(0.27)$. The multiplication of the multilocus outcrossing rate by the correlation of paternity showed that about $35 \%$ of the plants in the progenies were full-sib, and about $57 \%$, half-sibs. In addition, about $8 \%$ of the progenies were selfing-sibs. The estimate of the correlation of selfing, or the probability of finding an individual generated by selfing in the same place where there was another individual generated by selfing, was about $23 \%$, and this percentage was significant.

The result of correlation of paternity was high (0.379) and significantly different from zero, which demonstrated that part of the progenies were generated by the same maternal and paternal parentage, and that the progenies were not exclusively composed of half-sibs, but of a mix of half-sibs, full-sibs and selfing-sibs.

The mean number of individuals that effectively pollinate maternal trees may be estimated using the correlation of paternity, that is, the mean number of probable individuals that contributed pollen to the reproductive event of a maternal tree. The result was 2.6.

The difference between single-locus and multilocus correlations of paternity has been used to quantify relatedness between pollen donors. The value was negative, which indicated that the pollen for mating was rather diversified.

The estimated genetic differentiation coefficient within progenies was 0.139 . This coefficient was a measure of relatedness that estimates the probability of randomly sampling two alleles in two individuals who are identical by descent (GIUDICE NETO et al., 2005). For the population under study, there was about $14 \%$ probability of sampling two alleles in two individuals that were identical by descent. This differentiation coefficient of progenies in Q. grandiflora Mart is a consequence of the reproductive system of the species and biparental outcrossing, in addition to selfing of the adult trees, which was 0.38 . In progenies, the fixation rate was also high (about 27\%).

The estimate of the effective size $(\mathrm{Ne})$ was 13.2. These results are summarized in Table 2 .

\section{DISCUSSION}

The rate of fixation measures the excess or deficiency of homozygotes in relation to the expected proportions in populations at Hardy-Weinberg equilibrium. In tree species that reproduce by outcrossing, selfing may have negative effects on adaptation and reproductive capacity of small populations, and these effects are increased when generations overlap. In small populations, where there is no selection against homozygotes, as in the case of the results of our study, the rate of selfing and relatedness may increase rapidly and lead to inbreeding depression, characterized by loss of vigor, fertility, adaptation and reproductive capacity (ALLARD, 1971).

For a long time it was believed that pollination in natural populations was the result of the contribution of a large number of pollinating trees and that mating was predominantly random. However, the results for Qualea grandiflora Mart demonstrated that part of the progeny is formed by full-sibs. Therefore, the assumption that there are only exclusive half-sib progenies in this population may generate errors in the estimates of genetic parameters.

The estimate of the correlation of selfing suggests that there is a variation in the outcrossing rate between individual plants and that there is biparental inbreeding - the same maternal and paternal trees involved in successive mating. That is: there is a trend of some maternal plants to have a larger progeny by selfing or outcrossing than others, and the individuals resulting from selfing are randomly distributed in the progenies.

The correlation of paternity measures the proportion of individuals generated from biparental outcrossing (full-sibs). According to (GIUDICE NETO et al., 2005), biparental outcrossing may be a common phenomenon in several species. Studies about Caryocar brasiliense Camb(COLLEVATTI etal., 2001a) estimated the correlation of paternity from 0.212 to 0.324 . In a natural population

Revista Árvore, Viçosa-MG, v.39, n.2, p.337-344, 2015

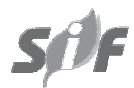


Table 2 - Estimates of parameters of the reproductive system in progenies of Q. grandiflora Mart. in Assis, SP, Brazil. Tabela 2 - Estimativa de parâmetros do sistema reprodutivo em progênies de Q. grandiflora Mart em Assis, SP, Brazil.

\begin{tabular}{lc}
\hline \multicolumn{1}{c}{ Parameter } & Result (standard error) \\
\hline Fixation index in adult population $(F)$ & $0.38(0.25-0.49)$ \\
Fixation index in progenies $\left(F_{p}\right)$ & $0.270(0.15-0.38)$ \\
Multilocus crossing rate $\left(\hat{t}_{m}\right)$ & $0.913(0.021)$ \\
Single-locus outcrossing rate $\left(\hat{t}_{s}\right)$ & $0.632(0.031)$ \\
Biparental inbreeding rate $\hat{t}_{p}=\hat{t}_{m}-\hat{t}_{s}$ & $0.281(0.023)$ \\
Correlation of selfing $\left(\hat{r}_{s}\right)$ & $0.235(0.046)$ \\
Correlation of paternity $\left(\hat{r}_{p}\right)$ & $0.379(0.047)$ \\
Relatedness between pollen donors $\hat{r}_{p}(\mathrm{~s})-\hat{r}_{p}(\mathrm{~m})$ & $-0.143(0.047)$ \\
Mean number of pollen donor trees $\left(N_{e p}=1 / \hat{r}_{p}\right)$ & 2.6 \\
Proportion of selfing-sibs $\left(s=1-\hat{t}_{m}\right)$ & 0.087 \\
Proportion of half-sibs $t_{m}=1-\hat{r}_{p}$ & 0.654 \\
Mean genetic differentiation within progenies $\theta_{p}$ & $0.139(0.105-0.177)$ \\
Effective progeny size $\left(N_{e}\right)$ & 13.2 \\
Number of trees to retain effective size of $50(m)$ & 95 \\
\hline
\end{tabular}

of Chorisia speciosa A. St. Hill (SOUZA et al., 2003), a correlation of 0.875 was found.

According to Sun and Ritland (1998), biparental outcrossing may be assigned to the behavior of pollinators, systematically aiming at neighboring trees and a small number of close neighbors, and to the asynchrony of tree flowering. Moreover, environmental variations may affect the density of the populations of pollinating animals and their behavior, which leads to changes in the rate of outcrossing of the species in different populations (MURAWSKI, 1995).

Therefore, the assumption that tree species apparently reproduce by random mating is not always true, and its adoption may add substantial errors to the estimates of genetic parameters in the study of the inheritance of quantitative characteristics used in programs to improve species, in the determination of sample sizes for gene improvement and conservation and in seed collection for reforestation (GIUDICE NETO et al., 2005).

The mean number of individuals that effectively pollinate maternal trees was low (2.6), which suggests that, despite the high density of trees, pollen flow is restricted in the population. As a consequence, the effective size retained in seed samples should be low when compared with an ideal panmictic population (GIUDICE NETO et al., 2005).
Similar studies focusing on the reproductive system of species in the Cerrado have reported similar results. In a study of Myracroduon urundeuva Fr. All in the southeastern region of Brazil, Moraes et al.(2004) detected two to three effective pollinators.

Medeiros(2010) studied Tabebuia aurea (Silva Manso) Benth. \& Hook. f ex S. Moore in the Brazilian Cerrado of the Distrito Federal in Brazil and detected a mean 4.8 number of effective pollinators in the reproductive seasons of one year. However, in the same area of that study, in the reproductive season of the next year, mean number of pollinators increased to 8.1 , which suggests that this number may be highly variable in the population according to different reproductive seasons.

The estimate of the effective size $(\mathrm{Ne})$ revealed that the genetic representativeness of progeny was lower than expected in random mating progenies. That is: the 300 samples analyzed corresponded to only 13.2 individuals of an ideal panmictic population.

The maximal value assumed by $\mathrm{Ne}$ for samples of an infinite size, or in the order of hundreds, in allogamous species is $4 n$, where $n$ is the number of plants; therefore, $\mathrm{Ne} /$ plant might reach the value of 4. $\mathrm{Ne} /$ plant was low (0.53). This value results from the finite size of plant progeny (12 seeds). In contrast, $N e$ might reach the maximal value of $100(4 \times 25)$. The value found here was 13.2 , which corresponds to $13 \%$

Revista Árvore, Viçosa-MG, v.39, n.2, p.337-344, 2015

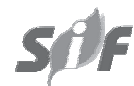


of the maximal value and reveals the existence of homozygosity in the progeny arrays, in agreement with the fixation indices for adults and progenies, which were 0.38 and 0.27 .

The estimates of effective size in progenies may contribute, in practical terms, to outlining strategies to collect seeds and for the genetic conservation of the species. The number of trees to collect seeds to keep the effective reference size may be determined according to this reference size and the mean effective size of each plant. Taking as a reference the effective size of 50 (FRANKEL; SOULÉ, 1981) and dividing it by the estimated $\mathrm{Ne} /$ plant $=0.53$ (calculated above), the result is 95 trees to collect seeds to ensure the retention of the effective size.

\section{CONCLUSION}

The results of this study demonstrated that selfing is found for Q. grandiflora Mart, and that this species reproduces by outcrossing and is not self-incompatible.

A considerable number of the progenies are fullsibs, but most are half-sibs. Mixed mating between plants of different families, either half-sibs or full-sibs, may reduce the effective size of the progeny array.

Seed collection demands a large number of trees (95) and preferably trees with distinct fruit, to preserve the genetic diversity of the species. If this number is used, seeds with an ideal genetic diversity may be obtained to be used in environmental recovery programs.

\section{ACKNOWLEDGMENTS}

We are grateful to Fundação de Amparo à Pesquisa do Estado de São Paulo (FAPESP) for financial support, to members of Laboratório de Reprodução e Genética de Espécies Arbóreas (LARGEA-Esalq/USP) for technical assistance and data processing, and to Lucas Antiqueira for revising the manuscript.

\section{REFERENCES}

\section{ALLARD, R.W. Princípios do melhoramento genético das plantas. São Paulo: Edgard Blucher, 1971. 381p.}

ALMEIDA, S.P., PROENÇA, C.E.B., SANO, S.M., RIBEIRO, J.F. Cerrado: espécies vegetais úteis. Planaltina: Embrapa Cerrados, 1998.
ANTIQUEIRA, L.M.O.R.; KAGEYAMA, P.Y. Genetic diversity of four populations of Qualea grandiflora Mart. in fragments of the Brazilian Cerrado.Genetica, v.142, n.1, p.11-21 2014.

AYRES, M. C. C. et al. Constituintes químicos das folhas de Qualea grandiflora: Atribuição dos dados de RMN de dois flavonóides glicosilados acilados diastereoisoméricos. Química Nova, v.31, n.6, p.1481-1484, 2008.

BARRET, S. C. H.; KOHN, J. The genetic and evolutionary consequences of small population size in plant: implications for conservation. In: FALK, D.; HOLSINGER, K. (Ed.). Genetics and conservation of rare plants. Oxford: University Press, 1991. p.3-30.

BREDE, E.G.; BEEBEE, T.J. Contrasting population structures in two sympatric anurans: implications for species conservation. Heredity, v.92, n.2, p.110-117, 2004.

COLLEVATTI, R.G.; GRATTAPAGLIA, D.; HAY, J.D. High resolution microsatellite based analysis of the mating system allows the detection of significant biparental inbreeding in Caryocar brasiliense, an endangered tropical tree species. Heredity, v.86, n.Pt 1, p.60-67, 2001 a.

COLLEVATTI, R.G.; GRATTAPAGLIA, D.; HAY, J.D. Population genetic structure of the endangered tropical tree species Caryocar brasiliense, based on variability at microsatellite loci. Molecular Ecology, v.10, n.2, p.349$356,2001 \mathrm{~b}$.

\section{CRESTE, S.; TULMANN NETO, A.; FIGUEIRA,} A. Detection of single sequence repeat polymorphisms in denaturing polyacrylamide sequencing gels by silver staining. Plant Molecular Biology Reporter, v.19, p.299306, 2001.

CROZIER, R. H.; OLDROYD, B.P.; TAY, W.T.; KAUFMANN, B.E.; JOHNSON, R.N.; CAREW, M.E.; JENNINGS K.M. Molecular advances in understanding social insect population structure. Electrophoresis, v.18, n.9, p.1672-1675, 1997.

DEMPSTER, A.P.; LAIRD, N.M.; RUBIN, D.B. Maximum likelihood from incomplete data via the EM algorithm (with discussion). Journal of the Royal Statistic Society, v.39, n.1, p.1-38, 1977. 
DOYLE, J.J.; DOYLE, J.L. Isolation of DNA from fresh tissue. Focus, v.12, p.13-15, 1990.

EFRON, B. Bootstrap methods: another look at the jackknife. The Annals of Statistics, v.7, p.1-26, 1979.

FERREIRA, M.E.; GRATTAPAGLIA, D.

Introdução ao uso de marcadores moleculares em análise genética. Brasília: Embrapa Cenargen, 1998. 220p.

FRANKEL, O.H.; SOULÉ, M.S. Conservation and evolution. Cambridge: Cambridge University Press, 1981.

FRANKHAM, R. Genetics and conservation biology. Comptes Rendus Biologies, v.326, Suppl 1, p.S22-29, 2003.

FRANKHAM, R. Conservation biology: ecosystem recovery enhanced by genotypic diversity. Heredity, v.95, n.3, p.183, 2005.

GIUDICE NETO, J.D.; SEBBENN, A.M.; KAGEYAMA, P.Y. Sistema de reprodução em Caesalpinia echinata Lam. implantada em arboreto experimental. Revista Brasileira de Botânica, v.28, n.2, p.409-418, 2005.

GOMES, C.C.; MOURA, T.M. Estrutura genética em populações de plantas do Cerrado. Agrotecnologia, v.1, n.1, p.33-51, 2010.

HILL, W.G. Estimation of effective population size from data on linkage disequilibrium. Genetical Research, v.38, p.209-216, 1981.

HITCHINGS, S.P.; BEEBEE, T.J. Genetic substructuring as a result of barriers to gene flow in urban Rana temporaria (common frog) populations: implications for biodiversity conservation. Heredity, v.79, Pt 2, p.117-27, 1997.

LEWIS, P.; ZAYKIN, D. Genetic data analysis: computer programe for the analyses of allelic data. 2000.

MCCLACHLAN, G.J.; KRISHNAN, T. The EM algorithm and extensions. New York: Wiley, 1997. 274p.

MEDEIROS, A.C.B.D. Fluxo de pólen e estrutura genética espacial em uma população de Tabebuia aurea na Estação Ecológica de Águas Emendadas,
DF. 2010. 124f. Tese (Doutorado em Ciências Genômicas e Biotecnologia) - Universidade Católica de Brasília, Brasília, 2010.

MITTERMEIER, R.A.; GIL, R.P.; HOFFMAN, M.; PILGRIM, J.; BROOKS, T.; MITTERMEIER, C.G.; LAMOREUX, J.; FONSECA, G.A. Hotspots revisited: earth's biologically richest and most endangered terrestrial ecoregions. Boston: Cemex, 2005.431p.

MORAES, M.L.T.; SEBBENN, A.M.; KAGEYAMA, P.Y. Correlated matings in dioicious tropical tree, Myracrodruon urundeuva Fr. All. Forest Genetics, v.11, n.1, p.53-59, 2004.

MOREIRA, P.A.; FERNANDES, G.W.;

COLLEVATTI, R.G. Fragmentation and spatial genetic structure in Tabebuia ochracea (Bignoniaceae) a seasonally dry Neotropical tree. Forest Ecology and Management, v.258, p.2690-2695, 2009.

MORENO, M. A. demais autores. Estrutura genética espacial em populações de Hymenaea stigonacarpa Mart. ex Hayne mediante a utilização de marcadores microssatélites cloroplastidiais. Scientia Forestalis, v.37, p.513-523, 2009.

MURAWSKI, B.A. Reproductive biology and genetics of tropical trees from canopy perspective. In: LOWMAN, M.D.; NADKARNI, N.M. (Ed.). Forest canopies. New York: Academic Press, 1995. p.457-493.

PAULA, J.E.D.; ALVES, J.L.H. Madeiras nativas: anatomia, dendrologia, dendrometria, produção e uso. Brasília: Empresa Gráfica Gutenberg, 1997.

PINHEIRO, E.S.; DURIGAN, G. Dinâmica espaçotemporal (1962-2006) das fitofisionomias em unidade de conservação do cerrado no sudeste do Brasil. Revista Brasileira de Botânica, v.32, p.441-454, 2009.

RIBEIRO, J.F.; WALTER, B.M.T. Fitofisionomias do bioma cerrado. In: SANO, S.; ALMEIDA, S. P. (Ed.). Cerrado: ambiente e flora. Planaltina: Embrapa Cerrados, 1998. p.87-166.

Revista Árvore, Viçosa-MG, v.39, n.2, p.337-344, 2015 
RITLAND, K.; JAIN, S. A model for the estimation of outcrossing rate and gene frequencies using independent loci. Heredity, v.47, n.1, p.35-52, 1981 .

RITLAND, K. Multilocus mating system program MLTR. 2009. Available in: <http:// genetics.forestry.ubc.ca/ritland/programs.html $>$. Accessed: 21 mai. 2014.

RITTER, L.M.O.; BAJAY, M.; MONTEIRO, M.; SOUZA, R.G.V.C.; MORENO, M.A.; KAGEYAMA, P.Y. Development of microsatellite markers for Qualea grandiflora Mart (Vochysiaceae), typical species of Brazilian Cerrado. American

Journal of Botany, v.99, n.3, 97-98, 2012.

SOARES, T.N.; CHAVES, L.J.; TELLES, M.P.C.; DINIZ-FILHO, J.A.F.; RESENDE, L.V. Landscape conservation genetics of Dipteryx alata ("baru" tree: Fabaceae) from Cerrado region of central Brazil. Genetica, v.132, n.1, p.9-19, 2008.

SOLÉ-CAVA, A.M. Biodiversidade molecular e genética da conservação. In: MATIOLI, S. R. (Ed.). Biologia molecular e evolução. Ribeirão Preto: Holos, 2001. p.172-192.

SOUZA, L.M.F.I.; KAGEYAMA, P.Y.; SEBBENN, A.M. Sistema de reprodução em população natura de Chorisia speciosa A. St.-Hil. (Bombacaceae). Revista Brasileira de Botânica, v.26, p.113-121, 2003.

SUN, M.; RITLAND, K. Mating system of yellow starthistle (Centaurea solstitialis), a successful colonizer in North America. Heredity, v. 80, p.225-232, 1998.
TARAZI, R. Diversidade genética, estrutura genética espacial, sistema de reprodução e fluxo gênico em uma população de Copaifera langsdorffii Desf. no Cerrado. 2009. 139f. Tese (Doutorado em Genética e Melhoramento de Plantas) - Escola Superior de Agricultura Luiz de Queiroz, Piracicaba, 2009.

TARAZI, R.; MORENO, M.A.; GANDARA, F.B.; FERRAZ, E.M.; MORAES, M.L.T.; VINSON, C.C.; CIAMPI, A. Y.; VENCOVSKY, R.; KAGEYAMA, P.Y. High levels of genetic differentiation and selfing in the Brazilian cerrado fruit tree Dipteryx alata Vog. (Fabaceae). Genetics and Molecular Biology, v.33, n.1, p.78-85, 2010.

TORRES, R.A. Novas fronteiras da biologia da conservação: a era da genômica. Natureza e Conservação, v.2, p.16-18, 2003.

VENCOVSKY, R. Tamanho efetivo populacional na coleta e preservação de germoplasmas de espécies alógamas. IPEF, v.35, p.79-84, 1987.

WAPLES, R.S. A bias correction for estimates of effective population size based on linkage disequilibrium at unlinked gene loci.

Conservation Genetics, n.7, p.167-184, 2006.

ZUCCHI, M.I.; PINHEIRO, J.B.; COELHO, A.S.G.; MORAIS, L.K.; COUTO, M.A.; CHAVES, L.J.; VENCOVSKY,R. Genetic structure and gene flow in Eugenia dysenterica DC in the Brazilian Cerrado utilizing SSR markers Genetics and Molecular Biology, v.26, n.4, p.449-457, 2003. 